\title{
Doctors urge disclosure of sickle cell trait
}

A group of physicians at the Boston Medical Center in Massachusetts is urging doctors to tell parents if their child is born carrying the sickle cell trait and to discuss it at several points during a child's life - advice that directly contradicts little-known policies in Ontario and Quebec of withholding sickle cell carrier status from parents unless they specially request it.

If a baby is born with sickle cell disease - the inherited blood disorder associated with intensely painful sickle cell crises, strokes and organ damage parents and doctors in Ontario and Quebec learn about it quickly, but that's not the case for sickle cell carriers, babies who have only one copy of the mutated gene that codes for sickle hemoglobin.

Dr. Patricia Kavanagh, a pediatrician in the Boston Medical Center's Department of Pediatrics, who coauthored an op-ed in JAMA, says that, although carriers do not have the disease, in her experience, parents want to be informed as a preventive measure.

Parents of carriers can have a genetic screening test to learn if they both carry the mutated gene and are thus at risk of having a child with sickle cell disease. They can then take steps, such as preimplantation genetic diagnosis, to prevent that outcome. In addition, children with the sickle cell trait face potential, rare risks once they reach adolescence, and the op-ed argues that teens and their families should be informed of these.

Sickle cell primarily affects people of African, West Indian, Mediterranean or Indian descent, and in Canada many of those affected live in Quebec or Ontario. Yet under rules established last year in Quebec and in 2010 in Ontario, families in those provinces rarely learn if their child is born with the sickle cell trait.

To find out, parents or health care providers must file a request. In Ontario, few people take that step. Dr. Pranesh Chakraborty, director of Newborn Screening Ontario, wrote in an email that the program "receives on average 50 carrier requests annually" of which about $30 \%$ are for infants found to be carriers. However, about 9000 carriers have been identified since 2006.

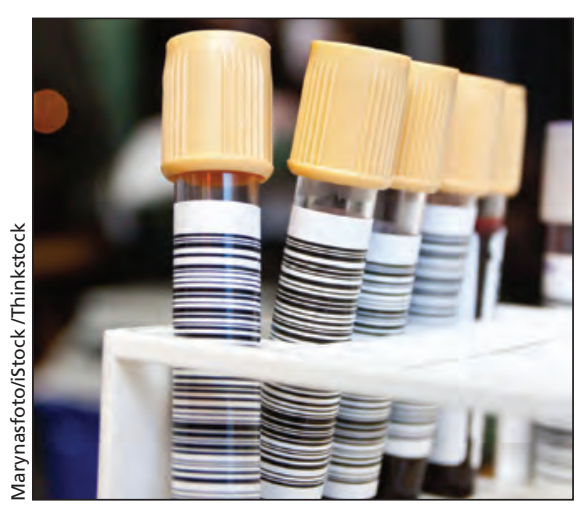

Under rules established last year in Quebec and in 2010 in Ontario, families rarely learn if their child is born with the sickle cell trait.

British Columbia also screens for sickle cell disease, and Nova Scotia initiated a sickle cell screening program on Apr. 1. In both provinces, parents are told if a child has the trait and receive information about it, as in the United Kingdom and in 50 US states.

The website of the Sickle Cell Association of Ontario links visitors to the request form that must be submitted to obtain the information. Lillie Johnson, the nurse who founded the association, thinks that's an unnecessary hurdle. "If we are out there teaching the people, educating them, why are we keeping important information from them?"

The Sickle Cell Anemia Association of Quebec's website boldfaces its message to parents, advising them to request a child's screening results and educate the child "on what it means" to be a sickle cell carrier.

Dr. Isaac Odame, medical director of the Global Sickle Cell Disease Network, says he has "struggled with some degree of disquiet" about how to communicate sickle cell trait to families in the context of "far from optimal" resources.

In a recent study in Ontario, $85 \%$ of parents said they would want to know if their child has the sickle cell trait. But Ontario's infrastructure for counselling families is deficient, he says, and without a good counselling system, families "don't even understand the information." Some of them think their children have mild sickle cell disease. - Miriam Shuchman, Toronto, Ont.

CMAJ 2014. DOI:10.1503/cmaj.109-4773 